\section{PP-349 陰荎癌症例における臨床的検討}

\title{
PP-351 成人停留精㠩の病理学的検討
}

\begin{abstract}
宝塚市立病院泌尿器科 ${ }^{1)}$, 市立川西病院泌尿器科 ${ }^{2)}$, 千 船病院泌尿器科 ${ }^{3)}$, 明和病院泌尿器科 ${ }^{4)}$, 兵庫医科大学 泌尿器科 ${ }^{5}$

東郷 容和 ${ }^{12}$, 福井 浩二 ${ }^{11}$, 中尾 篤 ${ }^{11}$, 古倉 浩次 ${ }^{11}$, 善本 哲郎 ${ }^{21}$, 川口 理作 ${ }^{3)}$, 土井 裕 ${ }^{4)}$, 薮元 秀典 ${ }^{4)}$, 丸山 环雄 ${ }^{5)}$, 近藤 宣幸 ${ }^{5}$, 野島 道生 ${ }^{5}$ ，

山本 新吾 $^{5}$, 島 博基 $^{5}$
\end{abstract}

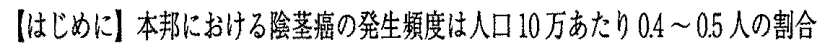

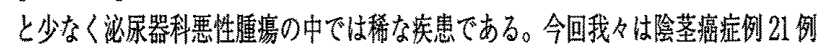
を経験したので報告する。䏒象及び方法】1993年1月加ら2007年2月までの間 に兵庫医科大学及びその関連施設に执いて経駼した陰茎癌症例 21 例を対象とした。

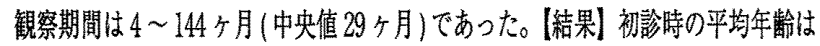

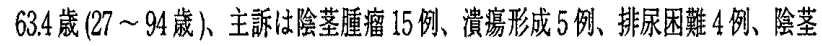

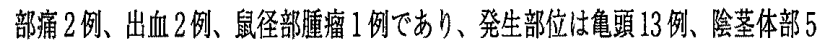

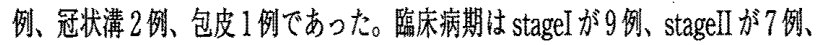
stageIII が3例、stageIVが2侧、T1が9例、T2が10例、T3が2例、NOが 16 例、N1が2例、N2が3例であった。陰茎部分切除16 例、陰茎全摘除4 例行い、 リンハ節郭清は 11 列に行った。全例 SCC(高分化型 15 例) であった。画像上、N 0 症例に対寸るリンハ節郭清は T1 \& 9 例中 4例、T2 \& 7 例中 4 例行ったが、いず

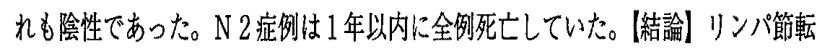
移の有無壮予後を左右すると思われた。以上の点を含的報告する。

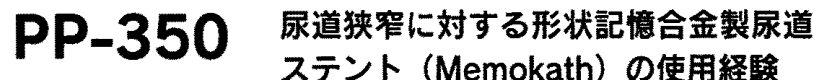

\author{
東邦大学医学部泌尿器科学講座 \\ 高杉 啓一郎, 神戸 茂樹, 永田 雅人, 山辺 史人, \\ 片岡 和義, 小林 秀行, 大平 直, 中島 耕一, \\ 栗田 稔, 永尾 光一, 原 啓, 石井 延久
}

我々の施設では外傷性尿道断裂後の尿道狭窄、外愓性尿 道狭窄、内視鏡手術後の尿道狭窄などの治療として形状 記憶合金製尿道ステントを使用している。従来の治療法 は、尿道ブジー、尿道拡張術、尿道切開術、開放性尿道 形成術などが行われていたが、術直後の良好な排尿が期 待しにくいこと、術後の再狭窄が大きな問題となってい た。一方、形状記憶合金製尿道ステントは、留置および 拔去が容易であること、永久留置型でないこと、留置直 後から良好な排尿が確保されること、約 1 年の留置で抜 去後の再狭窄が少なく、良好な排尿が期待できることか ら、尿道狭乍に対する有効な治療方法として期待される。 今回は 2001 年以降の当院での 25 症例の治療成績を 検討し、留置後のステント位置の移動、前後の狭窄など の合併症を考慮しつつ、より良い留置方法を考察し報告 する。

\author{
埼玉医科大学総合医療センター泌尿器科 \\ 吉永 敦史，山下 高久, 石井 信行, 松田 隆晴, \\ 寺尾 俊哉, 諸角 誠人, 山田 拓已
}

（緒言）日本小児泌尿器科学会の停留精巣ガイドラインでは、妊よう性 や悪性化などの観点から、その推奖手術時期について、1歳前後加ら 2歳頃が望ましいとしている。今回われわれは、成人停留精晕につい て、特に摘除した精巣の病理学的所見を中心に検討した。(対象と方法) 1985 年 8 月加 2007 年 7 月までの 22 年間に当科において手術を行った 停留精栄 208 例のうち、20歳以上は 15 例で、このうち 10 例に精坚摘除 術が行われた。(結果) 年龄は $26-56$ 歳、平均 38.9 歳、中央値 39 歳。 摘除理由として、2例は悪性疑い、8例は萎縮であった。悪性疑いの 2 例の病理学的所見は、精上皮腫と Mature cystic teratomaであった。萎 維精单の病理学的所見は、硝子化した組織のみが 3 例、Sertoli 練胞のみ が3例、成熟停止が2例であった。(考察) 停留精巣を経過観察した場 合、精細胞が減少もしくは消失する時期として、生後6 个月や 18 个月 など様々な報告がなされている。自験例についても、腫瘍症例を除く8 例はいずれも造精機能障害の所見を呈していた。一方で悪性化について は、10歳が critical pointであるとされている。自験例についても10例 中 1 例に精上皮腫を認めた。成人停留精巣が造精機能障害や腫瘍の発生 を高率に示すことから、停留精巣が成人期まで移行しないようにするた めに検診などでのスクリーニングの重要性が再認識された。

\section{PP-352 超音波上観祭される精巣内微細石灰
化の病理学的検討}

聖マリアンナ医科大学泌尿器科学 ${ }^{1)}$, 国際医療福祉大学 病院リプロダクションセンター ${ }^{2)}$, 聖マリアンナ医科大 学病院超音波センター ${ }^{3)}$, 聖マリアンナ医科大学病理学 ${ }^{4)}$ 中野 透点, 岩本 晃明 ${ }^{2)}$, 过本 文雄 ${ }^{3)}$, 高木 正之 ${ }^{4)}$, 野澤 資覀利 ${ }^{12}$ ，高橋 剛 ${ }^{\text {1) }}$

【目的】精栄内微細石灰化症（TM）の成因について検討する目的で精 巣病理標本を詳細に観察した【【方法】精巣腫瘍で精巣摘除した 23 症 例のう古古典的 TMの 5 症例（seminoma：4, teratoma：1）を対象

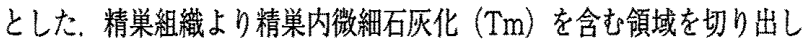
てパラフイン切片を作製し，HE染色およびvon Kossa 染色を行った。 光学影微镜下で全視野を観察し，Tm の有無，大きさ，形状，層状構造 の有無，染色性，および精細管の精子形成障害の程度を評価した、結 果および考察】以前より報告されている大きさより、より小さな $\mathrm{Tm}$ の存在が確認された。 5 症例全てにおいて hematoxylin body(HB) と laminated calcification(LC)の2タイプが混在していた。形態上 HBに 分類すべき石死片に層構造が見える例を散見し、HBと分類したものの 一部はLCである可能性が示唆された。 LCの大きさにより石灰化の程 度は異なっており、これは LCの基質部分の成長速度に起因するものと 考えられた。LC 周囲に注未熟な Sertoli cell の存在と精子形成異常が認 められ、それらと Tmの形成との関連が示唆された。 Tmの形成は精 巣の様々な病的変化のひとつとして提えるべきではないかと考光る。 